\title{
Tree-rings to climate relationships in nineteen provenances of four black pines sub-species ( Pinus nigra Arn.) growing in a common garden from Northwest Tunisia
}

Sondes Fkiri, Frédéric Guibal, Bruno Fady, Ali El Khorchani, Abdelhamid Khaldi, M. Larbi Khouja, Zouhair Nasr

\section{To cite this version:}

Sondes Fkiri, Frédéric Guibal, Bruno Fady, Ali El Khorchani, Abdelhamid Khaldi, et al.. Tree-rings to climate relationships in nineteen provenances of four black pines sub-species ( Pinus nigra Arn.) growing in a common garden from Northwest Tunisia. Dendrochronologia, Elsevier, 2018, 50, pp.44 51. $<10.1016 /$ j.dendro.2018.05.001 $>$. $<$ hal-01887088 $>$

\section{HAL Id: hal-01887088 \\ https://hal-amu.archives-ouvertes.fr/hal-01887088}

Submitted on 3 Oct 2018

HAL is a multi-disciplinary open access archive for the deposit and dissemination of scientific research documents, whether they are published or not. The documents may come from teaching and research institutions in France or abroad, or from public or private research centers.
L'archive ouverte pluridisciplinaire HAL, est destinée au dépôt et à la diffusion de documents scientifiques de niveau recherche, publiés ou non, émanant des établissements d'enseignement et de recherche français ou étrangers, des laboratoires publics ou privés. 


\title{
Tree-Rings to climate relationships in nineteen provenances of four black pines sub-species (Pinus nigra Arn.) growing in a common garden from Northwest Tunisia
}

\author{
Sondes Fkiri ${ }^{a, b *}$, Frédéric Guibal c, Bruno Fady ${ }^{d}$, Ali El Khorchani ${ }^{a}$, Abdelhamid Khaldi ${ }^{a}$, M. Larbi \\ Khouja a , Zouhair Nasr ${ }^{\text {a }}$
}

${ }^{a}$ National Research Institute of Rural Engineering, Water and Forestry (INRGREF), BP 10, Ariana 2080, Tunisie ${ }^{b}$ National institute of agronomy Tunis, BP 48, Tunis 1082, Tunisia

'Institut Méditerranéen de Biodiversité et d'Ecologie (IMBE), Aix Marseille Univ, Univ Avignon, CNRS, IRD, Europôle méditerranéen de l'Arbois, BP 80, 13545 Aix en Provence Cedex 4, France

dINRA, UR629, Ecologie des Forêts Méditerranéennes (URFM), Domaine Saint-Paul, 84914 Avignon Cedex 9, France

Corresponding author *: sondesfkiri@gmail.com

\section{Highlights:}
- $\quad$ Results expose differences in radial growth response to climate between subspecies of black pines.
- $\quad$ Spring water deficit seems to be the main constraint on black pine radial growth in Northwest of Tunisia.
- Low temperature and high temperatures effects on radial growth may become predominant in January/February and May/June for some subspecies and provenances of black pine.
- $\quad$ Our results also reveal differences between provenances attributable to genetic effects which will be further investigated in other common gardens submitted to other bioclimates.

Abstract: In the Mediterranean region, the effects of climate change on tree growth have been more and more noticeable in recent decades. Pinus nigra is one of the most common mid-elevation pine in this region and one of the species most affected by increasing dryness. In Tunisia, in order to guide species selection for future reforestation of the Khroumirie Mountains, research studies are under way to improve knowledge of black pine ecology. The effects of interannual climate variations on radial growth were compared for 19 provenances of black pine in a 51-year-old common garden experiment in Souiniet (NW Tunisia, 492m) in a humid Mediterranean bioclimate. A significant positive correlation with April precipitation and a significant negative correlation with spring temperature were noted. A cool wet spring is beneficial to growth as it affects tree water balance at the onset of the growing season; in 
contrast, spring drought is responsible for low annual growth. Mild January-February temperatures have a positive influence on ring width as mild winters may foster photosynthesis and promote early resumption of cambial activity. Analysis of the pointer years showed that winter snow and hail are major factors limiting growth of black pine in the studied area. Despite overall similarities in ring width to climate relationships among provenances, differences observed attest to the interaction of the environment and genetic control of black pine diameter growth.

Keywords: Pinus nigra Arn.; Tree-ring; Climate change; Dendroecology; Growth-climate response; Intraspecific variation; Provenances

\section{Introduction}

In the Mediterranean basin, drought is the main constraint to plants (Specht 1981). According to climatic models, a generalized rise in temperature and a decrease in precipitation, especially during the warm season, are expected well into the 21 st century in the Mediterranean basin along with other extreme events (IPCC, 2013). This climate change will modify the growth, productivity and distribution of tree species in this area (Leal et al., 2008; Martín-Benito et al., 2010; Martínez-Vilalta et al., 2008, Allen et al., 2010). In fact, the effects of climate change on forests will depend on how changes in water availability and temperature take place (Pichler and Oberhuber, 2007). Both negative and positive effects on forest growth have been observed. Summer and winter temperatures have opposite effects (negative and positive, respectively) on mean tree growth (Gea-Izquierdo et al. 2011; Andreu et al. 2007) while the effect of precipitation before growth resumes in the spring may be greater than summer precipitation (Piovesan et al. 2008, Leal et al., 2008; Martínez-Vilalta et al., 2008 Martín-Benito et al., 2010). In the Mediterranean basin, pine forests have been substantially affected by climate change in recent decades (Andreu et al., 2007, Leal et al., 2008; Martín-Benito et al., 2010a).

This study focuses on black pine which has shown recent evidence of sensitivity to climate change (Martin-Benito et al., 2010). Black pine (Pinus nigra Arn.) is a circumMediterranean pine species whose natural range extends from Spain and North Africa to Austria, Turkey and Cyprus. Most forests can be found in mountain areas between 1000 and $1500 \mathrm{~m}$ a.s.l. Its populations are fragmented and exhibit high morphological, physiological, genetic and ecological variability (Barbéro et al., 1998; Giovannelli et al., 2017). Owing to this large albeit discontinuous range and its large genetic and phenotypic variability, black 
pine is regarded as a collective species (Isajev et al., 2004). Although there is no definite consensus on its taxonomy, six main subspecies are currently recognized: $P$. nigra, salzmannii, dalmatica, pallasiana, laricio and mauretanica (Quézel and Medail, 2003). Black pine has been drawing some attention among forest managers because it is assumed to be relatively drought resistant and able to adapt to various soil types and climate conditions (Quézel and Barbéro, 1988; Costa et al., 1997).

Black pine is useful for studying the effects of climate change on tree growth. Several studies have addressed the degree to which black pines are affected by climate change by means of climate-growth relationships (Strumia et al. 1997, Köse et al. 2012, Levanic et al. 2013, Shishkova et al. 2013). Dendroecology is the main scientific approach used to evaluate the influence of climate on the growth of a species. Tree rings can also be used to assess the influence of forest management and climate on tree growth, productivity and mortality (Fritts 1976; Chen et al., 2010; Lapointe-Garant et al., 2010). Tree rings are very reliable indicators of forest health and decline (Dobbertin 2005). However, a large amount of factors contribute to ring-width variations which must be removed by standardization procedures from ringwidth series in order to isolate the influence of climate (Fritts 1976).

In France, $P$. nigra ssp. laricio has been found to be a drought sensitive species, and climate change might induce forest growth decline in the future (Lebourgeois, 2000; Amodei et al., 2013). In addition, the radial growth decline observed in the Western Mediterranean populations of black pine in Spain is consistent with increasing drought in the area, and in accordance with previous tree growth studies in dry-temperate regions (Martin-Benito, 2011). $P$. nigra has also been found to be drought sensitive: dry conditions before tree-ring formation are the major inhibitor of growth (Camarero et al., 2013). In eastern Iberia, it appears that climate change will compel decreasing radial growth because of increasing temperatures and decreasing precipitation (Macias et al., 2006; Piovesan et al., 2008). This trend of decreased radial increment has already been observed in some black pine populations from the Western Mediterranean basin (Martin-Benito et al., 2010). There have been many dendroclimatic studies on P. nigra for the western and central parts of the species distribution area (Biondi, 1992; Strumia et al., 1997, Richter et al., 1991, Fuster 2000, Leal et al., 2008, Andreu et al., 2008, Martin-Benito et al., 2008, Martin-Benito, 2010). In Bulgaria, P.nigra ssp. pallasiana seems well adapted to high summer temperatures and can resist low winter temperatures (Yurukov, 2003). 
Climate adaptation of trees involves both the genetic adaptation of populations and the ability of individuals to absorb environmental changes by modifying their phenotypical response (Mátyás, 1996). Adaptive capacities of forest trees to climatic change strongly depend on genetic diversity and geographic origins (Schaberg et al., 2008; Soto et al., 2010). Several studies have revealed an intraspecific variability in growth performance and different responses to climate, with the aim of selecting the provenances of $P$. nigra best adapted to the expected future climatic conditions. $P$. nigra is known for its relatively high individual and among-provenance and genetic diversity (Jagielska et al., 2007; Lucic et al., 2010; Seho et al., 2010, Giovannelli et al. 2017). Varelides et al (2001) showed differences in growth and significant site-provenance interactions of seventeen provenances of P. nigra from Greece, Turkey, Corsica and Calabria at three sites in northern Greece with different types of soils. In addition, according to Kreyling et al. (2012), cold hardiness of $P$. nigra differed between provenances, with provenances from colder regions showing a higher level of cold hardiness. Seedlings of six provenances of $P$. nigra exposed to drought and warming in a full factorial common garden experiment over two years showed that provenances of $P$. nigra differed strongly in their performance, while exhibiting a surprisingly uniform sensitivity to drought and mean temperature showing no sign of local adaptation (Thiel et., 2012). Growth analyses of four provenances of European black pine growing on dry sites in southwest Germany (Austria, Bosnia, France (Corsica), and Italy) revealed that the Corsican provenance differed from the three other provenances (Seho et al., 2010).

Adapting forest ecosystems to climate change is currently a major issue in forest management. Identifying suitable species or provenances is crucial when faced with environmental changes. In addition, insights into intraspecific variation in climate response are of paramount importance. In our study, we investigated intraspecific variation in climate response among black pine subspecies and provenances in a common garden located at the southern limit of its range. Provenance tests have the advantage of being able to compare different genotypes growing under similar climate conditions. From these tests, we were able to demonstrate the extent and distribution of genetic diversity in fitness-related traits of the tree species (Kremer et al., 2002, Savolainen et al., 2007). Few studies exploring interannual radial growth variations using common gardens have been conducted (Oleksyn et al., 1993; Savva et al., 2002, 2008; Seho et al., 2010). The objective of our study is to use a dendroecological approach to understand how different subspecies and provenances of black pine react to interannual climate variations in a common garden at Souiniet in the province of 
Ain Drahem (humid Mediterranean bioclimate). This type of study is necessary to understand which ecological factors drive ring-width variations within a species. Our aims were threefold: .(1) to compare mean radial growth and mean sensitivity of nineteen provenances, (2) to further determine what are the climatic variables influencing radial growth of black pine, and (3) to compare radial growth response to climate variations for different sub-species and provenances.

\section{Material and Methods:}

\section{Study Site:}

The experimental site was the Souiniet common garden located in the Khroumirie region in NW Tunisia (36 $48^{\prime} \mathrm{N}, 8^{\circ} 48 \mathrm{E}, 492 \mathrm{~m}$ ) (Fig. 1). It was established in 1966. The site is exposed to a humid Mediterranean bioclimate with temperate winters. The geological formations are dominated by Oligocene sandstones and varied clays. The soil is deep (180 $\mathrm{cm}$ ) with an balanced texture (Argilo-silty -sandy soils) but poor in organic matter and chemical material.

\section{Tree-ring sampling}

The Souiniet black pine experimental site was installed on 26 December 1964. The experimental design was: 21 complete blocks (A to U) of 399 trees, each block contains 19 trees representing 19 provenances. Trees were spaced $3 \mathrm{~m} \times 3 \mathrm{~m}$ apart.

The study focused on four subspecies of black pine (salzmanni, laricio, pallasiana, nigra) totaling nineteen provenances (Tab. 1). Two opposite cores were taken at breast height (1.30 $\mathrm{cm}$ ) from 4 to 13 trees per provenance using an increment borer (Tab.2). All cores were mounted on wooden supports and thoroughly polished with progressively finer sand paper.

\section{Meteorological data}

The monthly maximum and minimum temperatures and total precipitation data were collected from the Ain Drahem meteorological station (1969-2013) at an altitude of $676 \mathrm{~m}$, approximately $10 \mathrm{~km}$ from the experimental site. The average annual precipitation was approximately $1534 \mathrm{~mm} / \mathrm{yr}$. The mean annual temperature was $15.6^{\circ} \mathrm{C}$, the hottest month being July $\left(31^{\circ} \mathrm{C}\right)$ and the coldest January $\left(4.4^{\circ} \mathrm{C}\right)$ (Fig.1). In the study area, the dry period in summer lasts 3 months, from early June to the end of August. 


\section{Chronologies and climate-growth relationship analysis}

Tree-ring width measurement at $0.01 \mathrm{~mm}$ accuracy was provided by the semiautomatic LINTAB system and WinTSAP (LinntabRinntech®). Ring width series were crossdated using the TSAPwin ${ }^{\circledR}$ program. Ring widths were measured and indexed with standard methods by removing low- and intermediate-frequency variations using a polynomial function (Lebourgeois, 2010). Crossdating and data quality were validated using the Arstan program and Dendrochronology Program Library in R (dplR) (Merian and Lebourgeois, 2012).

Several statistics were calculated for the standardized chronologies. The mean sensitivity (MS) and first-order autocorrelation coefficient (AC) of the ring widths were calculated for each tree and averaged per subspecies and provenance. MS is a measure of year-to-year variability whereas AC estimates the influence of the previous year's growth upon that of the current year (Fritts, 1976).

The mean interseries correlation (Rbar) assesses the coherence in growth among trees (Briffa and Jones, 1990). In addition, the expressed population signal (EPS) was calculated for site chronologies to verify the crossdating and robustness of the climate signal (Wigley et al., 1984).

Pointer years were calculated on the average ring-width chronologies in order to highlight the years in which radial growth was particularly high or low.

For the purposes of statistical analysis and model fitting, we used the SAS ${ }^{\circ}$ statistical program. For analyses of variance, multiple comparisons of means, we used the generalized linear model (GLM) of SAS. The multiple comparison of means was done by using the Newman-Keuls method threshold risk 5\% (means with the same letters are not significantly different).

The relationship between climate and ring widths was investigated using bootstrapped response functions and the program 3pBase (Guiot and Goeury; 1996). Bootstrapped response functions were calculated using 24 monthly climatic parameters (mean monthly temperatures and total monthly precipitation from October of the previous year to September of the current year) as regressors and the master index chronology as the dependent variable. The bootstrap process method consists of calculating the regression on years drawn by lots. For each iteration, the regression coefficients and the multiple correlation of climatic regressors are computed on the years randomly selected (calibration years). An independent verification is 
carried out on the observations omitted from the subsample (verification years). The response function consists of the mean values and standard deviation of partial regression and correlation coefficients between actual values and values reconstructed from climate. The significance of each bootstrapped regression coefficient is provided by the ratio between the mean value calculated from the results of the simulations and its standard deviation. When the ratio equals 1.96 , the significance of the regression coefficients attains $95 \%$ probability (Lebourgeois, 2000).

\section{Results}

\section{Chronology statistics:}

Tree-ring series of individual trees showed an age-dependent trend similar among the studied provenances. The juvenile growth stage clearly exhibited a higher growth in provenance Tavola of sub-species laricio.

Comparing interannual variations of the mean curves of the 19 provenances showed good agreement in negative and positive peaks, confirmed by a high degree of common variance throughout several periods.

The analysis of variance showed significant differences between the mean ring widths of the 19 provenances of black pine. According to the Newman and Keuls test, there were three distinct groups, the lower group including Kustendil from the subspecies nigricans, which had the lowest ring width. Kustendil showed the highest expressed population signal (EPS, Tab.1). The EPS was below the critical value of 0.85 proposed by Wigley et al. (1984). Rbar and EPS were negatively correlated to the number of cores measured. Mean sensitivity varied between 0.23 for Saint Guilhem (subsp salzmanii) and 0.31 for Bois Frerot (subsp laricio) which expressed the highest high-frequency (year to year) variance. The first-order autocorrelation coefficient was above 0.7 in all provenances, emphasizing the high interannual correlation between ring widths (Tab.1).

\section{Pointer years}

The period from 1975 to 1986 was characterized by a high number of negative pointer years. From 1986, wide and narrow rings were noted alternately. In 1981, 1982, 1983 and 
1993 more than $60 \%$ of provenances showed a negative pointer year. 2004 was the only year in which more than $60 \%$ of provenances had a positive pointer year (Fig. 4).

Positive years were characterized by low amounts of annual precipitation and high temperatures (12 mm and $21{ }^{\circ} \mathrm{C}$ in 2004) for the two months (September and October) when black pine cones mature, compared to negative years (64 mm and $19{ }^{\circ} \mathrm{C}$ in 1993) (Fig. 5). The negative pointer years were characterized by winter snow and hail compared to positive years (Tab. 3).

\section{Climate-radial growth relationship}

Radial growth of black pine was positively affected by April precipitation and negatively correlated with May precipitation. Ring width was positively correlated with low January-February temperatures and negatively correlated with low spring temperatures (MayJune).

Three provenances, Brougatles (P1), Cazorla (P16) and Olette (P18) of subspecies salzmanni, Alaçam (P9) of subspecies pallasiana and Les Barres (P3) of subspecies laricio var. corsicana, were positively correlated to April precipitation (Fig. 6). Provenances P1 (Brogtles Ales), P3 (les barres), P6 (Puget-Théniers and P9 (Alaçam) were negatively correlated with May precipitation. Only three provenances of subspecies salzmanni (P1, P16 and P18) and two provenaces of subspecies laricio (P3 and P11) were negatively correlated with July precipitation (Fig. 6).

Low winter temperatures (January-February) were positively correlated with growth for eight provenances: four provenances of subspecies salzmanni (Brogtles Ales (P1), St Guilhem (Herault) (P12), Cazorla (P16) and Olette (P18), and four of subspecies laricio (Les Barres (P3), Grancia (P14), Aspromonto (P15) and Les Barres (leint) (P11)). All these provenances were negatively correlated with low temperatures at the end of spring (MayJune) (Fig. 6).

The radial growth of provenances Brougtles and Cazorla of subspecies salzmanni was negatively correlated with high temperatures in May and June (Fig. 6). 


\section{Discussion}

Black pine is a species with very high edaphic and climatic amplitude and is found on very different soils and bioclimates (Isajev et al., 2004). In fact, different provenances are adapted to different soil types from podzolic sands to limestone (Papaioannou 2015): Corsican, Italian and Sicilian origins grow poorly on limestone (Sevgi 2007) where pine requires deep soils. Conversely, Turkish and Crimean origins grow well on limestone. $P$. nigra subsp. pallasiana can be cultivated on both siliceous and calcareous soils. P. nigra subsp. salzmanni grows on calcareous soils better than P. nigra subsp. nigra which grows well on siliceous terrain. Austrian and Pyrenean provenances grow well on a wide range of soil types. The Albanian black pine usually prefers dolomites and serpentine soils (Dida et al., 2001).

In our study, we assessed radial growth to climate relationships in several black pine provenances growing in the same environment at the southern limit of the species' distribution range. April precipitation appears as the main critical environmental factor for radial growth of several black pine provenances. Positive correlations with April precipitation could be interpreted as a limiting effect of water deficit in April, a critical level of water supply triggering severe decrease in radial growth. Lebourgeois (1998) showed that rainfall deficits during the growing season lead to significant growth reduction of the two varieties of P. nigra subsp. laricio (corsicana and calabrica). In addition, Amodei et al. (2013) showed that Salzmann pine is sensitive to water deficit in spring. Other studies have pointed out that black pine is sensitive to high summer temperatures and water deficit in spring and summer (Martin-Benito et al., 2010; Lebourgeois, 2000; Génova and Fernández, 1999).

An insufficient water balance under high temperature conditions is responsible for low annual growth (Martin-Benito, 2008). We found a negative relationship with May precipitation for some provenances of black pine, confirming results obtained in the central Apennines (Italy) (Alma et al., 2014). Excessive rainfall in May and June may hamper cell wall thickening and therefore ring width. May and June temperatures are negatively correlated with ring width. Indeed, soil dryness caused by high evapotranspiration may lead to smaller 
needle formation which not only reduces water loss, but also the amount of photosynthates available for growth (Oberhuber et al., 1998). Negative relations with high May, June and July temperatures and Salzmann pine radial growth have been mentioned by other authors (Isajec, 2004; Amodei et al., 2013).

The positive relationship observed between radial growth and high January and February temperatures may reflect the beneficial effect of high temperatures on the resumption of cambial activity (Creber and Chaloner, 1990). High temperatures in winter make dormancy stimulate hormone secretion causing earlier cambial activation, thus increasing the length of the growing season (Bogino and Bravo, 2008).

Precipitation during the previous autumn has a positive effect on growth of the following year, whereas high temperature has a negative effect. Black pine shows greater sensitivity to high temperatures during the previous autumn as a result of their influence on carbohydrate accumulation and cambial zone formation (Martin-Benito et al., 2010b; Andreu et al., 2007).

In Mediterranean climates, cold winter temperatures and summer drought limit tree growth as trees face double stress. It snows almost every year from December to February in Souiniet, and particularly in January and February (Poupon, 1974). Although no snow damage has been reported since the installation of the Souiniet common garden, our study shows negative pointer years are sometimes characterized by snow and hail.

Tracing between-provenance variation probably represents the most powerful tool available for testing hypotheses of climatic adaptation in trees. Most of these studies are based on an analysis of the environmental and genetic control of height and diameter growth of provenances (Mátyás, 1997). Our results show similar patterns in ring width to climate relationships for different provenances. However, out of nineteen provenances, eight do not show any significant relationship with climatic variables. Therefore, despite similarities in ring width to climate relationships, differences occur among provenances which attest to the interaction of the environment and genetic controls of diameter growth. 


\section{Conclusion}

Spring water deficit seems to be the main constraint exerted on black pine radial growth in Northwest Tunisia. In addition, low temperature and high temperatures effects on radial growth are significant in January/February and May/June respectively for some subspecies and provenances. The balance between positive and negative effects of spring water availability and winter/spring temperatures on radial growth may determine the future performance of the provenances planted at Souiniet. Our results also reveal slight differences between provenances which could be attributable to genetic and genetic $\mathrm{x}$ environment effects. This should be further investigated in other common gardens submitted to other bioclimates. Future efforts should also include ecophysiological studies to better evaluate the P. nigra provenances that might be more adapted to the expected future average climatic conditions.

\section{References}

Allen C.D., Macalady A.K., Chenchouni H., et al., 2010. A global overview of drought and heat-induced tree mortality reveals emerging climate change risks for forests. Forest Ecology and Management 259, 660-684.

Alma, P., Matteo, G., Carlo, U., 2014. Structural attributes tree-ring growth and climate sensitivity of Pinus nigra Arn. at high altitude: common patterns of a possible treeline shift in the central Apennines (Italy). Dendrochronologia 32, 210-219.

Amodei, T., Guibal, F., Fady, B., 2013. Relationships between climate and radial growth in black pine (Pinus nigra Arnold ssp. salzmanni (Dunal) Franco) from the south of France. Annals of Forest Science 70, 41-47

Andreu, L., Gutierrez, E., Macias, M., Ribas, M., Bosch, O., Camarero, J.J., 2007. Climate increases regional tree-growth variability in Iberian pine forests. Glob Change Biol 13, 1-12 Barbéro, M., Lasiel, R., Quéezel, P., Richardson, D.M., Romane, F., 1998. Pine of the other medeterranean bassin In: Richardson, D.M (Ed.), Ecological and Biogeography of Pinus Cambridge University Press, Cambridge.

Andreu L., Planells O., Gutierez E., Helle G, Schleser, G., 2008. Climatic significance of tree-ring width and C13 C in a Spanish pine forest network. Tellus B 60, 771-781.

Biondi, F., 1999. Comparing trees ring chronologie repeated timber inventories as forest monitoring tools. Ecologicals application 9, 217-227. 
Bogino, S., Bravo, F., 2008. Growth response of Pinus pinaster Ait. to climatic variables in central Spanish forests. Annals of Forest Science 65, 506.

Briffa, K., and Cook, E.R., 1990. Methods of response function analysis. In Methods of dendrochronology. Edited by E. Cook and A.L. Kairiukstis. Kluwer Academic Publisher, Dordrecht, Nether- lands, pp. 240-247.

Camarero. J, Rub_en Manzanedo, R Sanchez-Salguero, R, Navarro-Cerrillo, R., 2013. Growth response to climate and drought change along an aridity gradient in the southernmost Pinus nigra relict forests. Annals of Forest Science, Springer Verlag/EDP Sciences 70 (8), 769-780.

Cook. E.R., Holmes, R.L., 1984. Program ARSTAN user manual: laboratory of tree ring research. University of Arizona, Tucson, AZ, USA.

Costa, M., Morla, C., Sainz, H., 1997. Los bosques ibéricos: una inter- pretación geobotánica. (ed). Planeta, Barcelona. 572 pp.

Creber, G.T., Chaloner, W.G., 1990. Environmental influences on cambial activity. In: The Vascular Cambium (Ed.: M. Iqbal). Research Studies Press Ltd. Taunton / John Wiley, Chickester, UK, pp. 159- 189.

Dida, M., Ducci, F., Zeneli, G., 2001. Black pine (Pinus nigra Arn.) resources in Albania, in Forest Genetic Resources No.29.www.fao.org/DOCREP/004/Y2316E/y2316e0d.htm, accessed 2011.02.25.

Fritts, H.C., 1976. Tree rings and climate. Academic Press, London.

Fuster, G., 2000. Tree rings and pointer years in the Sistema Central (Spain) in the last four hundred years. Boletin de la Real Sociedad Espanola de Historia Natural, Seccion Biologica 96(1-2), 33-42.

Gea-Izquierdo, G., Cherubini, P., Cañellas, I., 2011. Tree-rings reflect the impact of climate change along a temperature gradient in Spain over the last 100 years. Forest Ecology Management 262, 1807-1816.

Génova, M., Fernández, A., 1999. Tree rings and climate of Pinus nigra subsp. salzmanni in central Spain. Dendrochronologia 16-17, 75-85.

Giovannelli, G., Roig, A., Spanu, I., Vendramin, G.G., Fady, B., 2017. A New Set of Nuclear Microsatellites for an Ecologically and Economically Important Conifer: the European Black Pine (Pinus nigra Arn.). Plant Molecular Biology Reporter 35, 379-388.

Guiot, J., Gœury, C., 1996. PPPBASE, a software for statistical analysis of paleoecological and paleoclimatological data. Dendrochronologia 14, 295-300. 
IPCC., 2013.Climate Change 2013. The Physical Science Basis. Cambridge, Cambridge University.

Isajev, V., B. Fady, H. Semerci and V. Andonovski. 2004. EUFORGEN Technical Guidelines for genetic conservation and use for European black pine (Pinus nigra). International Plant Genetic Resources Institute, Rome, Italy. 6 p.

Jagielska, A., Cwalina, M., Prus-Glowacki, W., (2007): Genetic diversity of the black pine's stands (Pinus nigra. Arn.). SYLWAN 151, 23-31.

Köse, N., Akkemik, Ü., Dalfes, N., Özeren, M.S., Tolunay, D., 2012. Tree-ring growth of Pinus nigra Arn. subsp. pallasiana under different climate conditions throughout western Anatolia. Dendrochronologia 30: 295-301.

Kremer, A., Kleinschmit, J., Cottrell, J., Cundall, E.P., Deans, J.D., Ducousso, A., Konig, A.O., Lowe, A.J., Munro, R.C., Petit, R.J., Stephan, B.R., 2002. Is there a correlation between chloroplastic and nuclear divergence, or what are the roles of history and selection on genetic diversity in European oaks? Forest Ecology and Management 156, 75-87.

Kreyling, J., L.B. Wiesenberg, G., Thiel, D., Wohlfart, C., Huber,G., Walter, J., Jentsch, A., Konnert, M., Beierkuhnlein, C., 2012. Cold hardiness of Pinus nigra Arnold as influenced by geographic origin, warming, and extreme summer drought. Environmental and Experimental Botany 78, 99-108.

Lapointe-Garant, MP., Huang JG., Gea Izquierdo, G, Raulier., F,Bernier, P., et al., (2010). Use of tree rings to study the effect of climate change of trembling aspen in Quebec. Global Change Biology 16, 2039-2051.

Leal, S., Emaus, D., Grabner, M., Wimmer, R., Cherubini, P., 2008. Tree rings of Pinus nigra from the Vienna basin region (Austria) show evidence of change in climatic sensitivity in the late 20th century. Canadian Journal of Forest Research 38, 744-759.

Lebourgeois, F., 2000. Climatic signals in earlywood, latewood and total ring width of Corsican pine from western France. Annal of Forest Science 57, 155-164.

Lebourgeois F., 2010. Principles and methods of dendrochronology. UMR INRA-LERFOB 1092 - Forest Ecology Equipe Agro Paris Tech, ENGREF, pp. 10-21.

Lebourgeois, F., Mérian, P., 2012. Principes et méthodes de la dendrochronologie. Document de cours AgroParisTech, 90 pp.

Levanic, T., Popa, I., Poljansek, S., Nechita, C., 2013. A 323-year long reconstruction of drought for SW Romania based on black pine (Pinus nigra) tree-ring widths. International Journal of Biometeorology 57, 703-714. 
Lucic, A., Mladenovic-Drinic, S., Stavretovic, N., Isajev, V., Lavadinovic, V., Rakonjac, L., et al., 2010. Genetic diversity of Austrian Pine (Pinus nigra ARNOLD) populations in Serbia revealed by RAPD. Archives of Biological Sciences 62, 329- 336.

Macias, M., Andreu, L., Bosch, O., Camarero, J.J., Gutiérrez, E., 2006. Increasing aridityis enhancing silver fir (Abies alba Mill.) water stress in its south-Western distribution limit. Clim. Change 79, 289-313.

Martín-Benito, D., Cherubini, P., del Rio, M., and Cañellas, I. 2008. Growth response to climate and drought in Pinus nigra Arn. trees of different crown classes. Trees (Berl.) 22(3), $363-373$.

Martín-Benito, D., Del Rio, M., Can ellas, I., 2010. Black pine (Pinus nigra Arn.) growth divergence along a latitudinal gradient in Western Mediterranean Mountains. Annals of Forest Science 67(4), 401.

Martin-Benito, D., Del Rio, M., Cañellas, I., 2010. Black pine (Pinus nigra Arn.) growth divergence along a latitudinal gradient in Western Mediterranean Mountains. Annals of Forest Science 67,401

Martín-Benito, D., Del Río, M., Heinrich, I., Helle, G., Cañellas, I., 2010b. Response of climate-growth relationships and water use efficiency to thinning in a Pinus nigra afforestation. Forest Ecology and Management 259, 967-975.

Martín-Benito, D., Kint, V., Del Rio, M., Muys, B., and Cañellas, I. 2011. Growth responses of West-Mediterranean Pinus nigra to climate change are modulated by competition and productivity: past trends and future perspectives. Forest Ecology and Management 262(6), 1030-1040.

Martin-Benito, D., Hans, B., Isabel, C., 2013.Influence of drought on tree rings and tracheid features of Pinus nigra and Pinus sylvestris in a mesic Mediterranean forest. European Journal of Forest Research 132, 33-45.

Martínez-Vilalta, J., López, B.C., Adell, N., Badiella, L., Ninyerola, M., 2008. Twentieth century increase of Scots pine radial growth in NE Spain shows strong climate interactions, Glob. Change Biol 14, 2868-2881.

Mátyás, C., 1996. Climatic adaptation of trees: rediscovering provenance tests. Euphytica, 92, 45-54.

Mátyás, C., 1997. Genetics and adaptation to climate change: a case study of trees. In: Huntley B, et al. (eds) Past and future rapid environmental changes: the spatial and evolutionary responses of terrestrial biota. Springer, Berlin Heidelberg New York, 357-370. 
Oberhuber, W., Stumböck, M., Kofle,r W., 1998. Climate-tree-growth relationships of Scots pine stands (Pinus sylvestris L.) exposed to soil dryness. Trees 13, 19-27.

Oleksyn, J., Fritts, H.C., Hughes, M.K., 1993. Tree-ring analysis of different Pinus sylvestris provenances, Quercus robur, Larix decidua and L.decidua x L. kaempferi affected by air pollution. Arboretum Kornickie 38, 87-111.

Papaioannou, A.G., 2015. Ecological and soil conditions of black pine (Pinus nigra Arn.) stands in the area of the Russian Monastery at Mount Athos. Russian Journal of Ecology 46, 438-443.

Pichler, P., Oberhuber. W., 2007. Radial growth response of coniferous forest trees in an inner Alpine environment to heat-wave in 2003. Forest Ecology and Management 242, 688-69

Piovesan, G., Biondi, F., Di Filippo, A., Alessandrini, A., Maugeri, M., 2008. Drought driven growth reduction in old beech (Fagus sylvatica) forests of the central Apennines, Italy. Global Change Biology 14, 1265-1281.

Poupon, D., 1974. Principaux résultats de la station ecologique de Souiniet. Variété scientifique 8 .

Ritcher, K., Eckstein, D., Holmes, R.L., 1991. The dendrochronological Signal of pine trees (Pinus ssp.) in Spain. Tree Ring Bulletin 51, 1-13.

Savolainen, O., Kujala, S.T., Sokol, C., Pyhajarvi, T., Avia, K., Knurr, T., Karkkainen, K., Savva, Y., Schweingruber, F.H., Milyutin, L., Vaganov, E., 2002. Genetic and environmental signals in tree rings from different provenances of Pinus sylvestris L. planted in the southern taiga, central Siberia. Trees 16, 313-324.

Savva, Y., Bergeron, Y., Denneler, B., Koubaa, A., Tremblay, F. 2008. Effect of interannual climate variations on radial growth of jack pine provenances in Petawawa, Ontario. Canadian Journal of Forest Research 38, 619-630.

Schaberg, P., DeHayes, D., Hawley, G. \& Nijensohn, S., 2008. Anthropogenic alterations of genetic diversity within tree populations: implications for forest ecosystem resilience. Forest Ecology and Management 256: 855-862.

Seho, M., Kohnle, U., Albrecht, A., Lenk, E., 2010. Growth analyses of four provenances of European Black Pine (Pinus nigra) growing on dry sites in southwest Germany (BadenWuerttemberg). Allgemeine Forst und Jagdzeitung 181, 104- 116.

Sevgi, L.O., Akkemik, U., 2007. A dendroecological study on Pinus nigra Arn. at different altitudes of northern slopes of Kazdaglari, Turkey. J. Env. Bio 28, 73-75. 
Shishkova, V., Panayotov, M., 2013. Climategrowth relationship of Pinus nigra tree-ring width chronology from the Rhodope Mountains, Bulgaria. Bulgarian Journal of Agricultural Sciences. (in press).

Spiecker, H., 2002. Tree rings and forest management in Europe. Dendrochronologia 20, 191202.

Strumia, G., Wimmer R., Grabner M., 1997. Dendroclimatic sensitivity of Pinus nigra Arnold in Austria. Dendrochronologia 15, 129-137.

Quézel P., Médail F., 2003. Ecologie et biogéographie des forêts du bassin méditerranéen. Collection Environnement, Elsevier.

Thiel, D., Laura Nagy, L., Beierkuhnlein, C., Huber, G., Jentsch, A, Konnert, M., Kreyling, J., 2012. Uniform drought and warming responses in Pinus nigra provenances despite specific overall performances. For. Ecol. Management 270, 200-208.

Quézel P., Barbéro M., 1988. Signification phytoécologique et phyto- sociologique des peuplements naturels de Pin de Salzmann en France. Ecology Mediterranean 14, 41-63.

Vaganov, E. A., Hughes M. K., Shashkin, A. V., 2006. Growth Dynamics of Tree Rings: Images of Past and Future Environments, Springer, New York.

Varelides, C., Brofas G., Varelides, Y., 2001. Provenance variation in Pinus nigra at three sites in Northern Greece. Annals of Forest Sciences 58: 893-900 893.

Wigley, T.M.L., Briffa, K.R., and Jones, P.D., 1984. On the average value of correlated time series, with applications in dendroclimatology and hydrometeorology. Journal of Applied Meteorology and Climatology. 23(2), 201-213.

Yurukov S., 2003. Dendrology. Sofia, University of Forestry Press Housen, Bulgarian, 212 pp. 
Table 1: Provenances List and geographic origin.

\begin{tabular}{|c|c|c|c|c|c|c|}
\hline $\mathrm{N}^{\circ}$ & Sub-species & Provenances & $\begin{array}{l}\text { Country } \\
\text { of origin }\end{array}$ & Altitude & Latitude & Longitude \\
\hline $\mathrm{P} 1$ & Pinus nigra salzmanni & Brougatles & France & - & $44^{\circ} 07^{\prime} 35.4 \mathrm{~N}$ & $4^{\circ} 05^{\prime} 09^{\prime \prime} \mathrm{E}$ \\
\hline $\mathrm{P} 2$ & Pinus nigra calabrica & Trenta Coste (Sila Greca) & Italie & 1050 & $39^{\circ} 25 \mathrm{~N}$ & $16^{\circ} 35 \mathrm{E}$ \\
\hline P3 & Pinus nigra calabrica & Les Barres & France & 150 & $47^{\circ} 50 \mathrm{~N}$ & $2^{\circ} 45 \mathrm{E}$ \\
\hline P4 & Pinus nigra calabrica & Cosenza & Italie & 1300 & $39^{\circ} 15 \mathrm{~N}$ & $16^{\circ} 17 \mathrm{E}$ \\
\hline P5 & Pinus nigra corsicana & Bois frerot & France & 100 & & - \\
\hline P6 & Pinus nigra austriaca & Puget Theniers & France & - & $43^{\circ} 57^{\prime} 24.4 \mathrm{~N}$ & 6'53'53.0'’ E \\
\hline P8 & Pinus nigra nigricana & Kustentil & Bulgarie & $900-1100$ & $42^{\circ} 16 \mathrm{~N}$ & $22^{\circ} 41^{\prime} 49 \mathrm{E}$ \\
\hline P9 & Pinus nigra pallasiana & Alaçam & Turquie & $800-1000$ & $39^{\circ} 35 \mathrm{~N}$ & $28^{\circ} 35 \mathrm{E}$ \\
\hline $\mathrm{P} 10$ & pinus nigra calabrica & Catanzaro & Italie & - & $38^{\circ} 54 \mathrm{~N}$ & $16^{\circ} 34 \mathrm{E}$ \\
\hline $\mathrm{P} 11$ & Pinus nigra corsicana & les Barres (leint) & France & 150 & $47^{\circ} 50 \mathrm{~N}$ & $2^{\circ} 45 \mathrm{E}$ \\
\hline $\mathrm{P} 12$ & Pinus nigra salzmanni & Saint-Guilhem-le-Désert & France & $350-400$ & $43^{\circ} 41 \mathrm{~N}$ & $3^{\circ} 35 \mathrm{E}$ \\
\hline $\mathrm{P} 13$ & Pinus nigra pallasiana & Crimée & Russie & 500 & $44^{\circ} 33 \mathrm{~N}$ & $34^{\circ} 17 \mathrm{E}$ \\
\hline $\mathrm{P} 14$ & Pinus nigra calabrica & Grancia (Sila Greca) & Italie & 850 & $39^{\circ} 41 \mathrm{~N}$ & $16^{\circ} 58 \mathrm{E}$ \\
\hline $\mathrm{P} 15$ & Pinus nigra calabrica & Aspromonto & Italie & 1300 & $38^{\circ} 05 \mathrm{~N}$ & $16^{\circ} 00 \mathrm{E}$ \\
\hline P16 & Pinus nigra salzmanni & Cazorla & Espagne & 1500 & $37^{\circ} 50 \mathrm{~N}$ & $3^{\circ} 00 \mathrm{O}$ \\
\hline P17 & Pinus nigra calabrica & Tavola (Sila Greca) & Italie & 950 & $39^{\circ} 25 \mathrm{~N}$ & $16^{\circ} 35 \mathrm{E}$ \\
\hline $\mathrm{P} 18$ & Pinus nigra salzmonni & Olette & France & - & $42^{\circ} 36^{\prime} 01.0^{\prime}{ }^{\prime} \mathrm{N}$ & 2'14'25.8' E \\
\hline P19 & Pinus nigra calabrica & les Barres & France & 150 & $47^{\circ} 50 \mathrm{~N}$ & $2^{\circ} 45 \mathrm{E}$ \\
\hline $\mathrm{P} 20$ & Pinus nigra corsicana & Marghese & Corse & 1100 & $41^{\circ} 39 \mathrm{~N}$ & $9^{\circ} 12 \mathrm{E}$ \\
\hline
\end{tabular}


Table 2. Number of sampling and Dendrochronological characteristics of the raw ring-width data for 19 provenance of black pine. Values were calculated using ARSTAN (Cook and Holmes, 1984) and Dendrochronology Program Library in R

(Merian, 2012).

\begin{tabular}{|c|c|c|c|c|c|c|c|c|c|c|}
\hline $\mathbf{N}^{\circ}$ & Sub-species & Provenances & $\begin{array}{l}\text { Nember of } \\
\text { cores }\end{array}$ & $\begin{array}{l}\text { Nember } \\
\text { of trees }\end{array}$ & $\begin{array}{l}\text { Age at } \\
1.30 \mathrm{~cm}\end{array}$ & RG (mm) & MS & (AR1) & Rbar & EPS \\
\hline 1 & Pinus nigra salzmanni & Brougatles & 9 & 8 & 40 & $186.4 \mathrm{a}$ & $0.247 \mathrm{a}$ & $0.82 \mathrm{a}$ & $0.318 f$ & $0.823 \mathrm{dc}$ \\
\hline 2 & Pinus nigra calabrica & Trenta & 12 & 8 & 42 & $194.2 \mathrm{a}$ & $0.258 \mathrm{a}$ & $0.81 \mathrm{a}$ & $0.296 \mathrm{~d}$ & $0.834 \mathrm{bcd}$ \\
\hline 3 & Pinus nigra calabrica & Les Barres & 19 & 13 & 40 & $223.6 \mathrm{a}$ & $0.252 \mathrm{a}$ & $0.82 \mathrm{a}$ & $0.420 \mathrm{~d}$ & $0.916 \mathrm{ab}$ \\
\hline 4 & Pinus nigra calabrica & Cosenza & 9 & 8 & 39 & $165.3 \mathrm{ab}$ & $0.269 \mathrm{a}$ & $0.83 \mathrm{a}$ & $0.233 \mathrm{~g}$ & $0.733 \mathrm{ef}$ \\
\hline 5 & Pinus nigra corsicana & Bois frerot & 20 & 10 & 40 & $171.5 \mathrm{a}$ & $0.307 \mathrm{a}$ & $0.81 \mathrm{a}$ & $0.236 \mathrm{~g}$ & $0.848 \mathrm{bcd}$ \\
\hline 6 & Pinus nigra austriaca & Puget-Théniers & 6 & 5 & 35 & $171.4 \mathrm{ab}$ & $0.286 \mathrm{a}$ & $0.83 a$ & $0.393 \mathrm{~g}$ & $0.651 \mathrm{~g}$ \\
\hline 8 & Pinus nigra nigricana & Kustendil & 6 & 4 & 40 & $104 b$ & $0.28 \mathrm{a}$ & $0.79 a$ & $0.040 \mathrm{~h}$ & $0.020 \mathrm{~h}$ \\
\hline 9 & Pinus nigra pallasiana & Alaçam & 8 & 5 & 42 & $183.1 \mathrm{a}$ & $0.268 \mathrm{a}$ & $0.81 \mathrm{a}$ & $0.317 f$ & $0.788 \mathrm{de}$ \\
\hline 10 & Pinus nigra calabrica & Cantanzaro & 5 & 5 & 41 & $184.9 \mathrm{ab}$ & $0.245 \mathrm{a}$ & $0.82 \mathrm{a}$ & $0.484 \mathrm{c}$ & $0.824 \mathrm{dc}$ \\
\hline 11 & Pinus nigra corsicana & les Barres (leint) & 14 & 8 & 41 & $198.5 \mathrm{a}$ & $0.242 \mathrm{a}$ & $0.79 \mathrm{a}$ & $0.554 \mathrm{~b}$ & $0.554 \mathrm{~d}$ \\
\hline 12 & Pinus nigra salzmaenni & St Guilhem & 8 & 8 & 40 & $169.9 \mathrm{ab}$ & $0.232 \mathrm{a}$ & $0.78 \mathrm{a}$ & $0.449 \mathrm{dc}$ & $0.867 \mathrm{bcd}$ \\
\hline 13 & Pinus nigra pallasiana & Crimée & 10 & 6 & 42 & $178.9 \mathrm{a}$ & $0.251 \mathrm{a}$ & $0.83 \mathrm{a}$ & $0.286 f$ & $0.800 \mathrm{de}$ \\
\hline 14 & Pinus nigra calabrica & Grancia & 18 & 12 & 40 & $178.2 \mathrm{a}$ & $0.291 \mathrm{a}$ & $0.77 \mathrm{a}$ & $0.490 \mathrm{c}$ & $0.942 \mathrm{a}$ \\
\hline 15 & Pinus nigra calabrica & Aspromonto & 8 & 6 & 41 & $158.1 \mathrm{ab}$ & $0.271 \mathrm{a}$ & $0.76 \mathrm{a}$ & $0.242 \mathrm{~g}$ & $0.719 f$ \\
\hline 16 & Pinus nigra salzmaenni & Cazorla & 7 & 7 & 41 & $203 \mathrm{ab}$ & $0.264 \mathrm{a}$ & $0.81 \mathrm{a}$ & $0.364 \mathrm{e}$ & $0.8 \mathrm{de}$ \\
\hline 17 & Pinus nigra calabrica & Tavola & 6 & 4 & 42 & $168.6 \mathrm{a}$ & $0.299 \mathrm{a}$ & $0.84 \mathrm{a}$ & $0.292 \mathrm{f}$ & $0.712 \mathrm{f}$ \\
\hline 18 & Pinus nigra salzmanni & Olette & 10 & 8 & 43 & $162.3 \mathrm{ab}$ & $0.251 \mathrm{a}$ & $0.81 \mathrm{a}$ & $0.433 d$ & $0.884 b c$ \\
\hline 19 & Pinus nigra calabrica & les Barres & 4 & 4 & 42 & $176.8 \mathrm{a}$ & $0.277 \mathrm{a}$ & $0.85 \mathrm{a}$ & $0.677 \mathrm{a}$ & $0.893 \mathrm{abc}$ \\
\hline 20 & Pinus nigra corsicana & Marghese & 18 & 10 & 42 & $179 \mathrm{ab}$ & $0.247 \mathrm{a}$ & $0.84 \mathrm{a}$ & $0.758 \mathrm{a}$ & $0.940 \mathrm{a}$ \\
\hline
\end{tabular}

Variables abbreviations are: MG Mean ring widths ( $\mathrm{p}=0.0004<0.05)$, MS Mean Sensitivity is measure of year -to -year variability $(\mathrm{p}=0.01<0.05)$, AC first-order autocorrelation coefficient of ring widths ( $\mathrm{p}=0.396>0.05)$, Rbar running mean inter-series Correlation $(\mathrm{p}=0.0001<0.05)$, EPS expressed population signal $(\mathrm{p}=0.0001<0.05)$.

Values with the same letter are not statistically different. 
Table 3: Snow and Hail winter

\begin{tabular}{|c|c|c|c|}
\hline \multirow[t]{2}{*}{ Years } & \multicolumn{3}{|c|}{ Months } \\
\hline & December & January & February \\
\hline 1981 & $* S$ & $* * S$ & \\
\hline 1982 & $* * S$ & $* * S$ & \\
\hline 1983 & & $* S$ & $* S$ \\
\hline 1991 & & & $* * * S$ \\
\hline 1993 & & $* S$ & $* * * * * * \mathrm{H}$ \\
\hline 1994 & $* * \mathrm{~S}+* * * * * \mathrm{H}$ & & \\
\hline 2001 & & & $* * * * \mathrm{H}$ \\
\hline 2002 & $* * * * * S$ & & \\
\hline 2003 & & $* S$ & $* * * * * * * \mathrm{H}$ \\
\hline
\end{tabular}

S: Snow; H: Hail; *: Number of day 


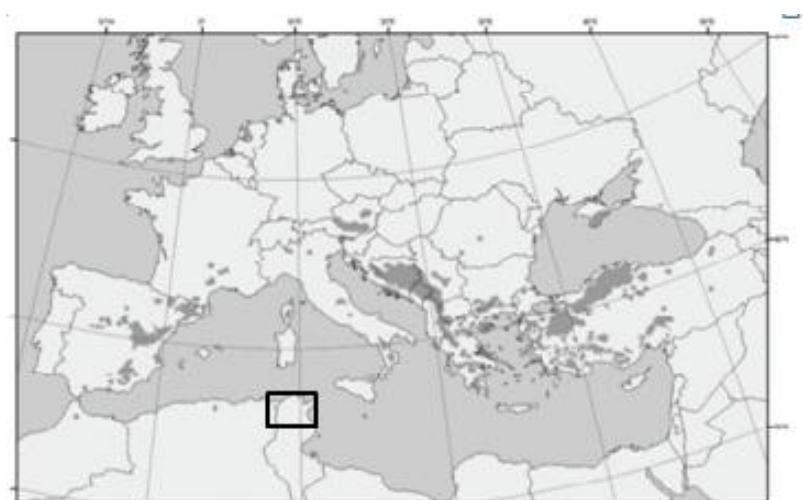

Natural Distribution area of black pines in (Sub)-

Mediterranean (According to Euforgen)

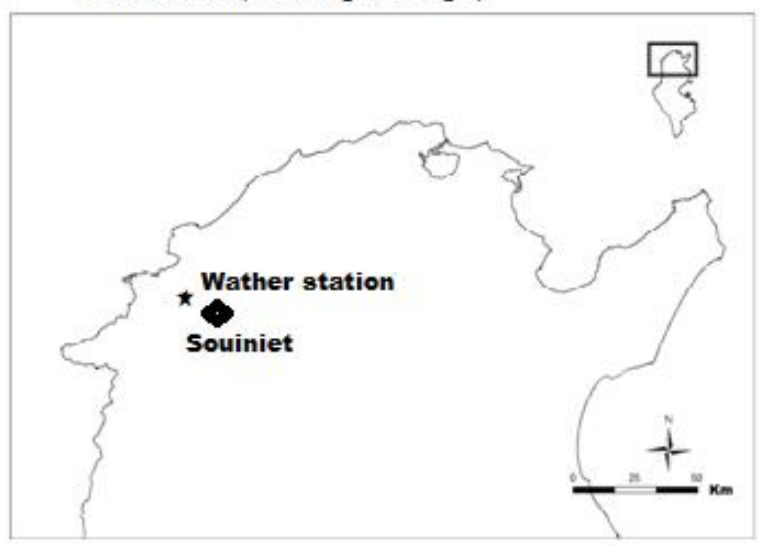

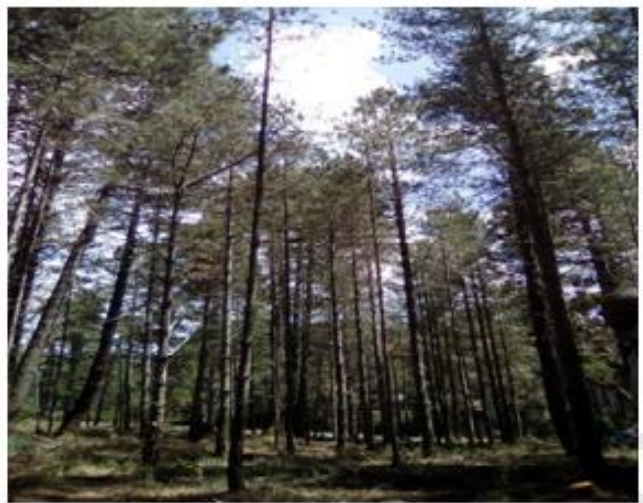

Black pine plantation at Souiniet station: Ain Drahem-Tunisia (Photo: S. Fkiri 2014)

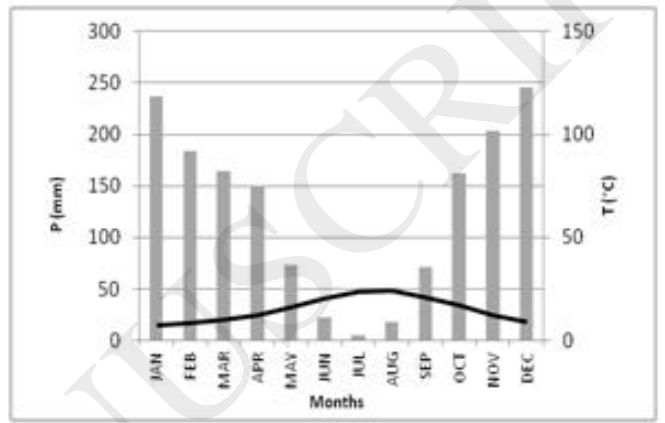

Ombrothermic diagram conducted using mean precipitations $(P)$ and mean temperature $\left(T^{\circ} \mathrm{C}\right)$ from the period $1950-2013$

Fig. 1. Location of studied site. 


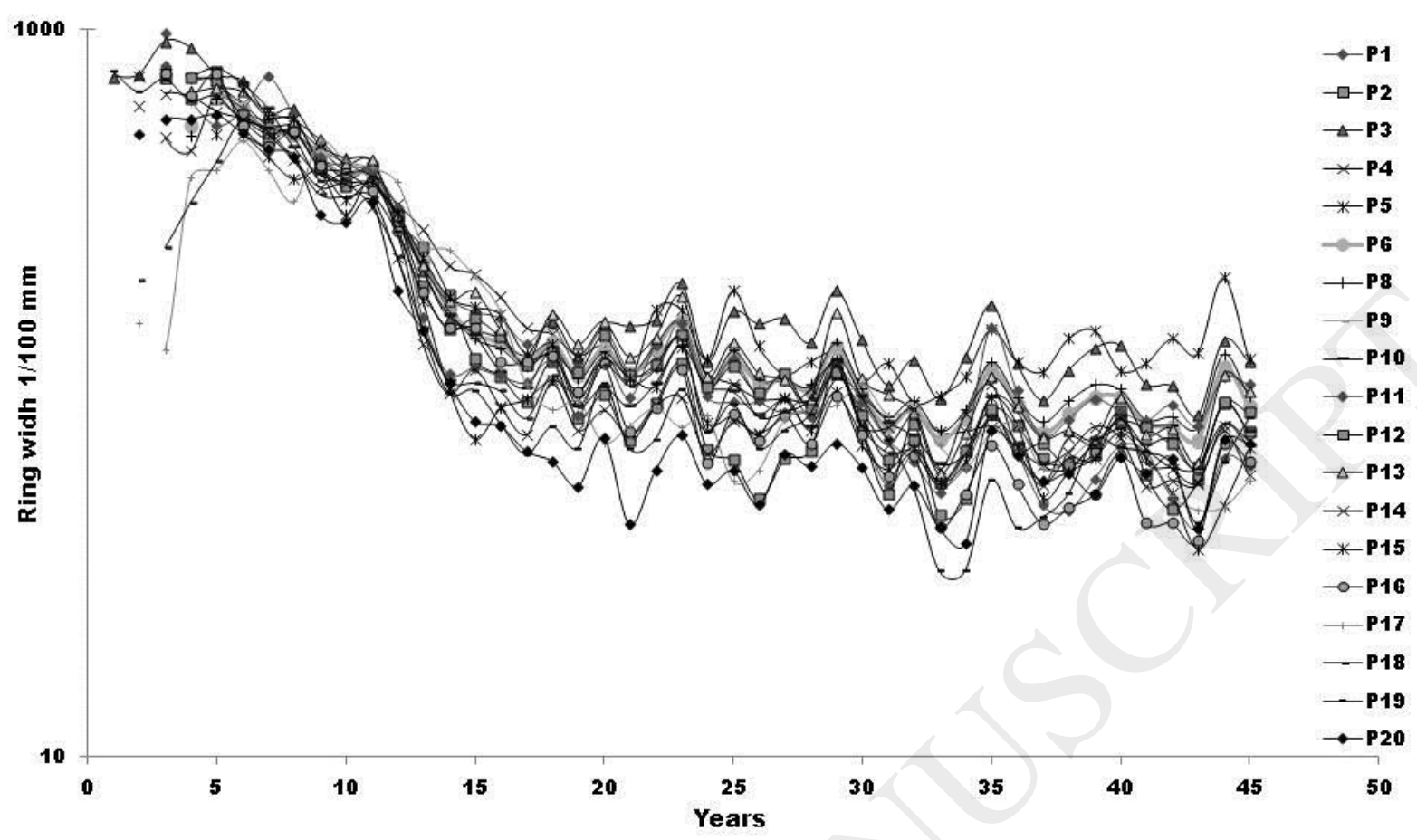

Fig. 2. Ring width chronologies for 4 black pine Sub-species planted in 1964 in the northwest of Tunisia. 


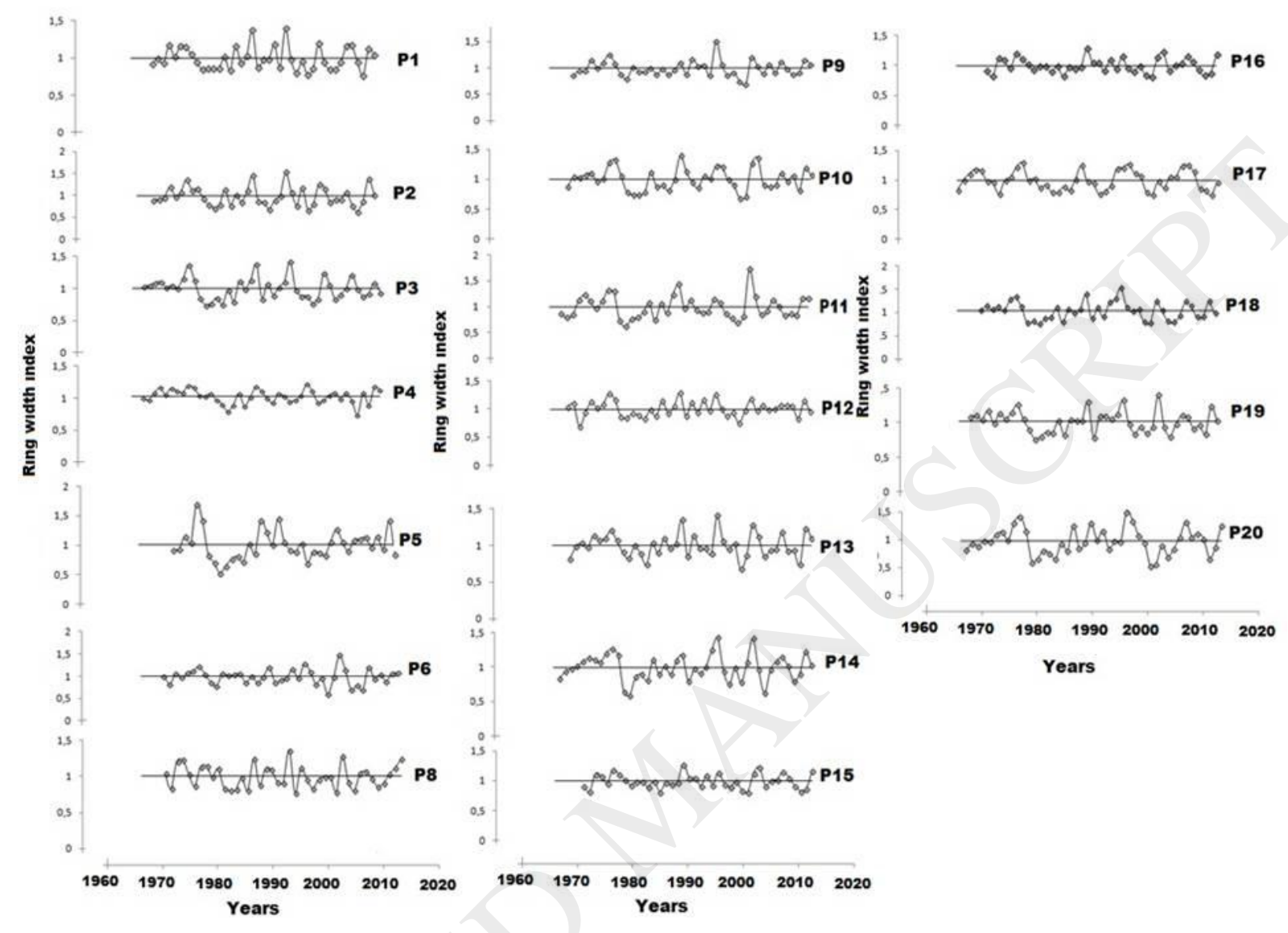

Fig. 3. Ring width index chronologies averaged accoss 19 provenances of Pinus nigra species planted in 1964 in the northest of Tunisia. 


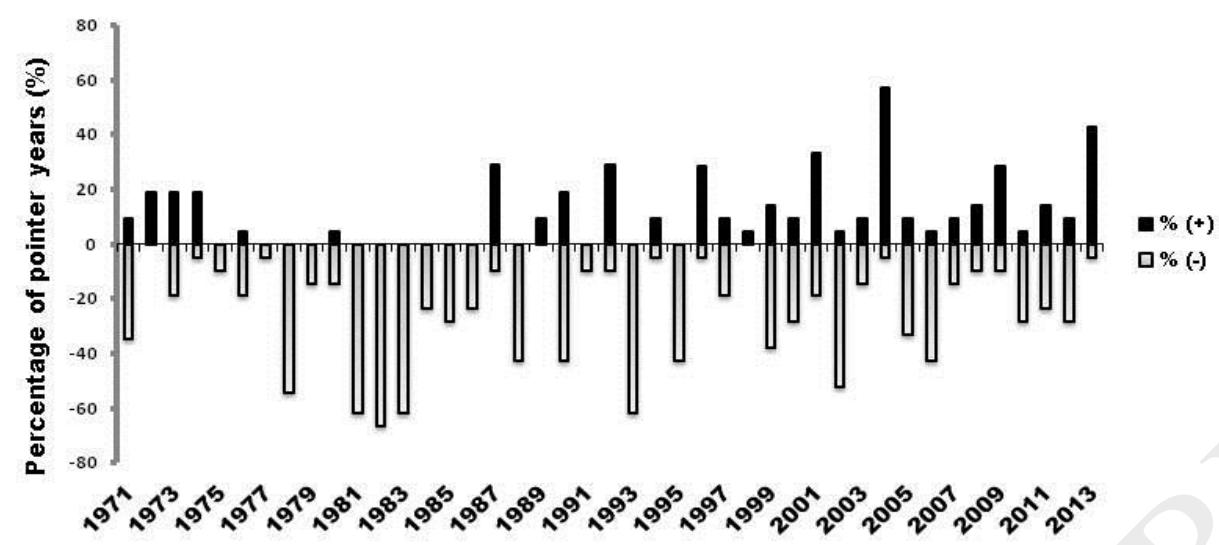

Fig. 4. Percentage of pointer years for period 1971-2013 from 19 provenances of black pine. 

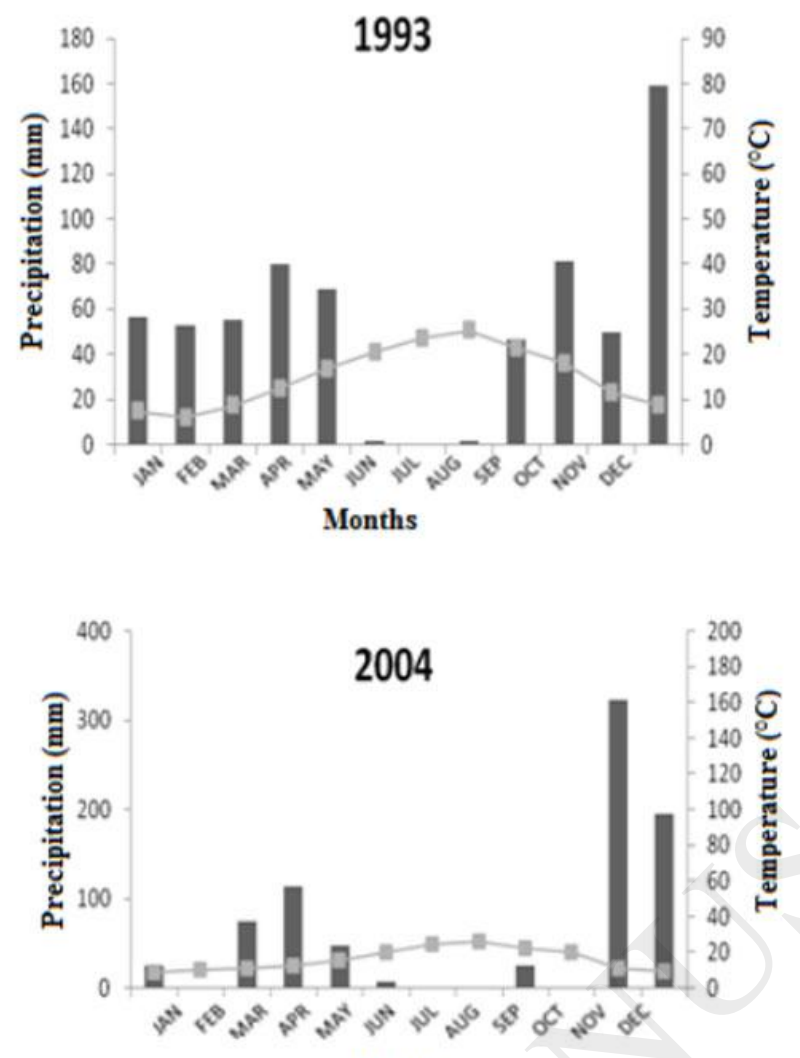

Months

Fig. 5. Ombrothermic diagrams from the average precipitation $(\mathrm{mm})$ and temperature $\left({ }^{\circ} \mathrm{C}\right)$ from the period of negative (1993) and positive (2004) characteristics. 


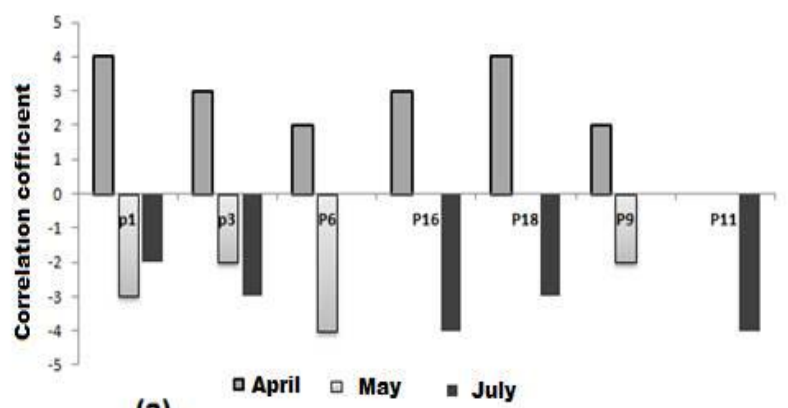

(a)

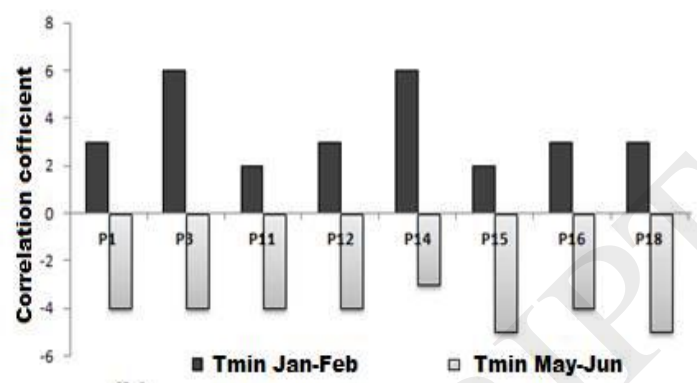

(b)

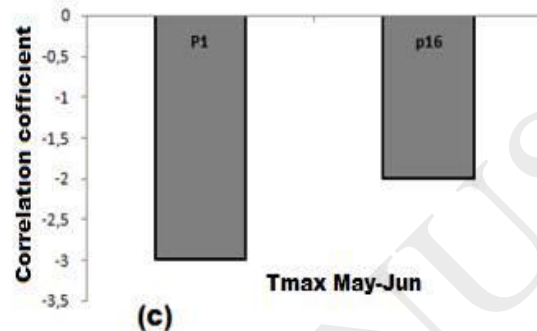

Fig. 6. Response function of Pinus nigra ring-widht to: (a) Precipitation from April, May and July (b) to monthly minimal temperature (Tmin) from January -February and May-June (c) to monthly maximal temperature (Tmax) from May-June 